First Draft: November, 2007

This Draft: April 18, 2008

\title{
The High-Volume Return Premium and Post-Earnings Announcement Drift*
}

\author{
Alina Lerman** \\ New York University \\ alerman@stern.nyu.edu \\ Joshua Livnat \\ New York University \\ jlivnat@stern.nyu.edu \\ and \\ Richard R. Mendenhall \\ University of Notre Dame \\ rmendenh@nd.edu
}

\begin{abstract}
This paper investigates the relationship among trading volume around earnings announcements, earnings forecast errors, and subsequent returns. Prior research finds a positive relation between earnings announcement period trading volume and subsequent returns (the high-volume return premium) and between earnings forecast errors and subsequent returns (post-earnings announcement drift). We find that for a sample of firms followed by analysts these effects are complementary, i.e., each retains incremental ability to predict post-earnings announcement returns. Prior research provides two competing explanations for the high-volume return premium: changes in firm visibility versus differences in risk. We provide evidence that seems to rule out risk-based explanations while supporting the visibility hypothesis.
\end{abstract}

*The authors are grateful to Charter Oak Investment Systems, Inc. for the Point-In-Time Compustat data available through WRDS, and to Paul Tetlock for providing counts of media stories on the S\&P 500 firms. The authors also acknowledge the contribution of Thomson Financial for providing forecast data available through the Institutional Brokers Estimate System. These data have been provided as part of a broad academic program to encourage earnings expectations research.

**Address correspondence to Alina Lerman, Department of Accounting, Stern School of Business Administration, New York University, 10-99C K-MEC Hall, 44 W. 4th St., 10th Fl., New York, NY 10012, (212) 998 - 0009 alerman@stern.nyu.edu

JEL Classification: G14

Keywords: Market efficiency; Trading Volume; High-Volume Return Premium; Post-earnings announcement Drift. 


\title{
The High-Volume Return Premium and Post-Earnings Announcement Drift
}

\begin{abstract}
This paper investigates the relationship among trading volume around earnings announcements, earnings forecast errors, and subsequent returns. Prior research finds a positive relation between earnings announcement period trading volume and subsequent returns (the high-volume return premium) and between earnings forecast errors and subsequent returns (post-earnings announcement drift). We find that for a sample of firms followed by analysts these effects are complementary, i.e., each retains incremental ability to predict post-earnings announcement returns. Prior research provides two competing explanations for the high-volume return premium: changes in firm visibility versus differences in risk. We provide evidence that seems to rule out risk-based explanations while supporting the visibility hypothesis.
\end{abstract}




\section{Introduction}

Recent research documents a positive relation between abnormal share trading volume around earnings announcements and subsequent returns. This empirical regularity is sometimes called the high-volume return premium. An extensive body of research also documents a positive relation between earnings forecast errors — both time series and analyst — and returns following earnings announcements. This anomaly is commonly referred to as the standardized unexpected earnings (SUE) effect or post-earnings announcement drift (PEAD). We show that these two effects are complementary - neither subsumes the other. Further, we show that another measure of earnings surprise, the abnormal return around the earnings announcement, also maintains some predictive power after controlling for both the high-volume premium and PEAD. Two explanations for the high-volume return premium appear in the literature. One argument is that the announcement period volume causes (or at least signals) changes in stock visibility that give rise to differences in post-announcement returns. Others argue that announcement period volume signals differences in stock risk levels and the high-volume return premium represents fair compensation for risk. We present results that appear to rule out risk-based explanations for the high-volume return premium and findings that support the visibility explanation.

Gervais, Kaniel, and Mingelgrin [2001] find a significant positive correlation between abnormal trading volume over short periods — e.g., one day or week — and subsequent returns. They dub their newly discovered anomaly the "high-volume return premium." While Gervais et al choose arbitrary days and weeks over which to estimate abnormal volume, Garfinkel and Sokobin [2006] extend their findings by documenting a positive correlation between abnormal share trading volume in the three-day period around earnings announcements and abnormal returns over the subsequent 60 trading days.

Another anomaly, which, in contrast, has received much attention in the academic literature is the post-earnings announcement drift (PEAD) — the significant positive relation between earnings forecast errors and subsequent returns. PEAD has been verified by numerous 
studies going back to Ball and Brown [1968]. Since both PEAD and the high-volume return premium represent associations between ex ante observable variables and returns following earnings announcements, we test them together. We find that the high-volume return premium survives when controlling for several measures of earnings surprise. We then turn our attention to the possible causes of this premium.

Gervais et al [2001] and Garfinkel and Sokobin [2006] differ in their explanations for the high-volume return anomaly. Gervais et al conclude that a shock in the stock's trading activity affects its visibility. A short period of highly abnormal volume causes or signals a change in the interest of investors: higher volume implies greater investor awareness and greater demand for the stock's shares. This greater demand manifests itself over the next 20 to 100 trading days in the form of high returns. Garfinkel and Sokobin, on the other hand, interpret the high-volume return premium as compensation for differential risk levels across stocks. Specifically, they view abnormal volume around the earnings announcement as an indicator of investor opinion divergence, and opinion divergence as a risk factor: higher volume implies greater divergence in investor opinion about firm value and higher stock riskiness. Higher stock riskiness, in turn, implies higher future equilibrium returns. We perform a battery of tests designed to discriminate between the two possible explanations on our sample of analyst-followed firms. Our findings contradict the risk-signal hypothesis and support the visibility hypothesis.

The rest of this paper is organized as follows. The next section reviews relevant literature, expands the issues mentioned above, and motivates our specific hypotheses. The third section defines our variables and describes our sample. The fourth section presents and discusses our empirical results and the final section concludes. 


\section{Literature Review and Hypothesis Motivation}

We investigate two basic issues. First, what is the relationship between the high-volume return premium and post-earnings announcement drift? Does one of these anomalies subsume the other or do they complement one another? Because we find that the high-volume return premium continues to exist when controlling for earnings forecast errors, the second issue becomes relevant. Our second issue is, Which of two proposed explanations for the high-volume return premium — visibility or risk — is more consistent with the data? In this section we briefly discuss the two anomalies, discuss the relevant literature, and motivate our tests.

\subsection{THE HIGH-VOLUME RETURN PREMIUM}

Gervais, Kaniel, and Mingelgrin [2001] are the first to document a positive association between short period (i.e., one day or week) abnormal volume and subsequent stock returns, which they call the high-volume return premium. They begin by dividing calendar time between 1963 and 1996 into non-overlapping 50-trading day periods. They use the first 49 days as a reference period and the $50^{\text {th }}$ day as the portfolio-formation day. For each period, each stock whose formation-day trading volume ranks it in the top (bottom) five days of the reference period plus the formation day, i.e., in the top (bottom) 10 percent, is placed in the high- (low-) volume portfolio. Gervais et al show that the high volume portfolio outperforms the low volume portfolio for periods from one to 100 trading days beginning one day after the portfolio-formation day. ${ }^{1}$

Gervais et al hypothesize that the high-volume return premium is caused by an association between trading-volume shocks and a firm's visibility. That is, a high-volume shock causes - or indicates that an event has occurred that causes - a stock to become known to more investors. Over the next few weeks, as some of these newly cognizant investors decide to purchase the stock, it exhibits high returns. In price-quantity space, one can imagine a downward sloping demand curve shifting out and intersecting a fixed vertical supply curve at a higher point.

\footnotetext{
${ }^{1}$ Here we describe tests based on a one-day portfolio-formation period. Gervais et al [2001] also perform tests based on a one-week portfolio-formation period; methods and inferences based on these tests are similar to those reported.
} 
Gervais et al cite Miller [1997], who suggests that, in the presence of short sales constraints, shares will be held by those who are most optimistic. If investors' expectations of value are unbiased and the supply of shares is small relative to the total potential demand, then prices will increase as more investors become aware of the firm.

Gervais et al [2001] provide two pieces of evidence in support of the visibility hypothesis. First, they posit that if changes in visibility are responsible for the subsequent high returns, then the high-volume return premium should not require high contemporaneous return shocks. They find that the anomaly exists even in cases where formation-period returns are near their reference period mean, i.e., for firms with very normal event day returns. Further, they hypothesize that visibility should be more important to stocks that are out of favor or neglected. Gervais et al use low reference period returns as a proxy for firms that have fallen out of favor and are neglected as of the event day. They find that the high-volume return premium is significantly stronger for firms that exhibited relative low (below the cross-sectional median) returns during the prior 49-day reference period.

Gervais et al [2001] show that their results are robust to a wide range of research design choices. For example, their results are not caused by outliers, the price momentum effect (Jegadeesh and Titman [1993]), or differences in the average betas of high- and low-volume stocks. Further, their conclusions are insensitive to omitting firms that announce earnings or make a dividend payment in the three-day period centered on the formation day.

Unlike Gervais et al [2001], who intentionally choose arbitrary formation periods without reference to specific events, Garfinkel and Sokobin [2006] test for a high-volume return premium based on the volume around earnings announcements. Garfinkel and Sokobin believe that announcement period trading volume is increasing in three factors: investor liquidity demands; the information content of the earnings announcement; and "more divergent opinions about the implications of the earnings news" (p. 90). Garfinkel and Sokobin attempt to control for the first two factors and hypothesize that post-earnings announcement returns will be increasing in the 
remaining component of abnormal volume. That is, Garfinkel and Sokobin interpret "unexplained volume as an indicator of opinion divergence and conclude that post-event returns are increasing in opinion divergence" (p.85).

Garfinkel and Sokobin [2006] do indeed find that post-earnings announcement returns are positively correlated to abnormal announcement period trading volume. This is true both unconditionally and when controlling for earnings announcement period returns as a measure of earnings surprise. ${ }^{2}$ Garfinkel and Sokobin state that Hong and Stein's [1999] model predicts that post-announcement returns will be declining in announcement period volume for negative earnings surprise firms, while Varian's [1985] model predicts the opposite. Both models predict that the returns will be increasing in volume for positive surprise firms. Garfinkel and Sokobin find that post-announcement returns are in fact increasing in announcement period volume whether the earnings surprise is positive or negative. They interpret Varian's theory as indicating that ex ante opinion divergence is an additional risk factor. Garfinkel and Sokobin conclude, therefore, that the positive correlation between announcement period volume and postannouncement returns is caused by a positive association between announcement period volume and price-relevant risk. In other words, the greater the opinion divergence today, the greater the risk, the lower the current price, and the higher future returns. Recall that this conclusion disagrees with that of Gervais et al [2001], who attribute the high-volume return premium to changes in stock visibility—not differences in risk.

\subsection{POST-EARNINGS ANNOUNCEMENT DRIFT}

As capital market anomalies go, post-earnings announcement drift (PEAD) is as old and well scrutinized as the high-volume return premium is new and unexplored. It is essentially the positive correlation between measures of quarterly earnings surprise and subsequent abnormal returns. PEAD (also known as the SUE—-standardized unexpected earnings — effect) was first discovered by Ball and Brown [1968] and quickly appeared in the (mostly finance) literature

\footnotetext{
${ }^{2}$ Note that Garfinkel and Sokobin [2006] do not control for either time series or analyst forecast errors.
} 
throughout the 1970s (e.g., Jones and Litzenberger [1970], Litzenberger et al [1971], Joy et al [1977], Latané and Jones [1977, 1979]). Ball [1978, 1992] and Bernard and Thomas [1989] provide comprehensive reviews of the early literature.

Despite decades of research, we are still not sure why the PEAD exists. We know that it is generally larger for smaller, lower-priced, less-liquid firms with less institutional following (e.g., Latané and Jones [1979]; Bernard and Thomas [1989]; Bhushan [1994]; Bartov et al [2000]). While this provides clues as to why sophisticated investors do not arbitrage the anomaly away, it does not help to explain why it exists in the first place. Prior research has provided little support for risk-based arguments (e.g., Rendleman et al [1982]; Bernard and Thomas [1989]), so the current predominant belief is that PEAD represents an underreaction to the information in earnings announcements. Some prior research (e.g., Bernard and Thomas [1990]; Bartov [1992]; Ball and Bartov [1996]) suggests the effect may be caused in part by a specific form of investor misestimation of the time series properties of earnings. Jacob et al [2000] disagree and Livnat and Mendenhall [2006] present results suggesting that PEAD may be caused by a more general underreaction to earnings information.

Finally, despite dozens of papers on PEAD, none to our knowledge investigates the effects of announcement period volume on subsequent returns. When documenting the highvolume return premium, Garfinkel and Sokobin [2006] attempt to control for earnings surprise using announcement period returns, but they do not use any form of earnings forecast error - the measure of earnings surprise for virtually all drift studies.

\subsection{RESEARCH QUESTIONS AND HYPOTHESES}

As discussed above, we address two research questions. The first is: What is the relationship between the high-volume return premium and post-earnings announcement drift? The second research question is: Which of the two proposed explanations for the high-volume return premium - changes in visibility or differences in risk - is more consistent with the data? Here we motivate hypotheses related to the two research questions. 


\subsubsection{Research Question 1: Are the high-volume return premium and post-earnings \\ announcement drift complementary or does one subsume the other?}

Addressing the first research question is straightforward. We perform both portfolio and regression tests to determine if post-earnings returns depend on both announcement period volume and forecast errors. Garfinkel and Sokobin [2006] use only the abnormal return at the time of the earnings announcement to control for earnings surprise when testing for a highvolume return premium. In an efficient market, the abnormal return in response to an earnings announcement is the best possible measure of the surprise contained in that announcement. If, however, post-earnings announcement drift represents an underreaction to earnings information, then the magnitude of the stock return at the time of the earnings announcement may be increasing in the information content of the earnings announcement, but decreasing in the degree of underreaction. The announcement period stock return may not, therefore, be the best predictor of future returns. For example, say that two identical firms, A and B, each announce earnings that imply a $10 \%$ increase in stock value. In an efficient market, the price of each stock immediately increases by $10 \%$. But say that the immediate reaction for stock $\mathrm{A}$ is $8 \%$ and that of $\mathrm{B}$ is $4 \%$. If PEAD represents a delayed stock price reaction to the earnings information, the drifts for stocks A and $\mathrm{B}$ will be $2 \%$ and $6 \%$, respectively. In this case the immediate stock price response to earnings will be a poor indicator of subsequent returns.

Several papers have compared the various earnings surprise measures and have considered whether they subsume or complement each other in explaining PEAD. Foster, Olsen, and Shevlin [1984] find that post-announcement returns are unrelated to the two-day $(-1,0)$ abnormal return around the announcement divided by the daily return standard deviation of the

firm's returns over the prior 250-trading day period. But Chan, Jegadeesh, and Lakonishok [1996] find that the four-day $(-2,+1)$ market adjusted return around earnings announcements predicts subsequent returns roughly as well as seasonal random walk (SRW) earnings forecast errors, a common measure of earnings surprise used in PEAD studies. When Chan et al compare 60-day 
post-announcement abnormal returns across extreme deciles, they obtain a difference of $5.9 \%$ for the abnormal return measure and $6.8 \%$ for SRW forecast errors and find that neither variable subsumes the other in the ability to predict future returns. Brandt, Kishore, Santa-Clara, and Venkatachalam [2006] also find that both announcement period abnormal-returns and earnings forecast errors predict post-earnings returns and that neither subsumes the other. ${ }^{3}$

The findings of Chan et al [1996] and Brandt et al [2006] suggest that it is necessary to control for both the announcement-period abnormal return and earnings forecast errors when assessing the high-volume return premium. Further, Livnat and Mendenhall [2006] suggest that, ceteris paribus, while analyst forecast errors predict larger post-earnings drifts than do time-series errors, they do not subsume time series errors' ability to predict future returns. (See also Lerman, Livnat, and Mendenhall [2007].)

Taking into accounting prior literature we answer the first research question by examining whether the announcement period volume has incremental predictive power for PEAD when controlling for three alternative measures of earnings surprise: the time series based earnings surprise, the analyst forecast based earnings surprise, and the announcement period abnormal return.

\subsubsection{Research Question 2: Which of the two proposed explanations for the high-volume return} premium is more consistent with the data?

Gervais et al [2001] conclude that the high-volume return premium is probably caused by a positive correlation between volume shocks and stock visibility. Garfinkel and Sokobin [2006], on the other hand, believe the anomaly is caused by risk differences across stocks. They infer that volume shocks are caused by investor belief divergence and that belief divergence is positively related to the riskiness of the stock. We generate a battery of tests to discriminate between these two alternatives.

\footnotetext{
${ }^{3}$ The question of why abnormal announcement period returns (as in Chan et al [1996] and Brandt et al [2006]) predict post-announcement returns, while announcement period returns deflated by non-event period volatility (as in Foster et al [1984]) do not, may be of interest in its own right. But the issue is beyond the scope of this paper.
} 


\subsection{2.a. The riskiness of simulated trading strategies.}

If the high-volume return premium represents a fair return to risk, there should be some evidence of this in the data. We assess the risk-return statistics of a strategy of buying (shorting) stocks that exhibit particularly high- (low-) announcement period trading volume. If the highvolume return premium is attributable to risk, then a strategy designed to profit from it should be risky.

\subsection{2.b. Abnormal volume and signal agreement.}

We next attempt to find surrogates for opinion divergence. Battalio and Mendenhall [2005] find that one class of investors (those initiating small trades) transacts in response to SRW earnings forecast errors while another class (those initiating large trades) responds to analyst forecast errors. So, the difference between SRW and analyst forecast errors may represent the divergence of opinions between more and less sophisticated investors. In our next set of tests, therefore, we examine announcement period trading volume for cases where SRW and analyst forecast errors are confirmatory and where they are contradictory. If measures of short-window abnormal volume are primarily driven by opinion divergence, then contradictory signals of earnings surprise should lead to greater trading volume.

\subsection{2.c. Analyst earnings forecast dispersion as a measure of opinion divergence.}

Like Garfinkel and Sokobin [2006], we next examine a variable that would seem to be a reasonably direct measure of investor opinion divergence - the dispersion (cross-sectional standard deviation) in analysts' forecasts of upcoming quarterly and annual earnings. While the disagreement of different types of forecast errors may indicate opinion divergence between more and less sophisticated investors (as in 2.3.2.b. above), disagreement among relatively sophisticated investors may be more relevant to pricing. Dispersion in analysts' forecasts may be able to capture this type of opinion divergence.

Garfinkel and Sokobin find that returns following earnings announcements are negatively associated with the pre-announcement dispersion of analysts' annual earnings forecasts as well as 
the change in dispersion around the time of the announcement. ${ }^{4}$ To the extent that analyst forecast dispersion captures investor opinion divergence, these tests contradict a key premise of their paper. To obtain the dispersion results they use very stringent data requirements that rule out over $86 \%$ of sample observations, i.e., requiring three forecasts within 30 days prior to the announcement and three forecasts within 10 days following the announcement. They also point out that for this subsample their measure of abnormal volume is not significantly related to postannouncement returns, whether or not they control for analyst dispersion measures. Garfinkel and Sokobin raise three possible explanations for why these results seem to contradict their explanation for the high-volume return premium. First, they may be wrong; returns may actually be declining in investor opinion divergence. Second, there may be a selection bias problem when limiting a sample to firms followed by analysts. Third, it may be that trading volume carries a different meaning when analyst forecasts are available. They suggest the evidence points to the second and third explanations, but not the first.

We reopen these issues by performing tests to determine whether announcement period trading volume and the change in analyst forecast dispersion seem to capture similar phenomena. Specifically, using a less restrictive sample, we examine the correlation between these two variables as well as the effect of each on the announcement period and subsequent returns. If forecast dispersion and announcement volume are positively correlated and have the same effect on immediate and subsequent returns, this would provide evidence in support of Garfinkel and Sokobin's interpretation of announcement period volume as a measure of divergence in investor opinion. If, however, when examining a sample more than a dozen times larger than that examined by Garfinkel and Sokobin [2006], forecast dispersion and volume are negatively associated or if they have different effects on returns, this would suggest that something other than opinion divergence causes the high-volume return premium.

\footnotetext{
${ }^{4}$ Ackert and Athanassakos [1997] and Diether et al [2002] find generally that analyst forecast dispersion is negatively correlated with future returns.
} 


\subsection{2.d. The association between abnormal volume and contemporaneous abnormal returns.}

The differential risk hypothesis holds that higher announcement period volume signals higher future expected returns, implying that investors understand event volume as an indicator of risk and that the market re-prices stocks to reflect this risk. This suggests that higher than expected volume will be associated with lower contemporaneous returns; an event that signals the price-relevant risk of a stock is higher (lower) than the market previously thought will be associated with a contemporaneous drop (rise) in the stock's price.

Consider, for example, a stock in a CAPM world. The market receives a signal on Wednesday morning that increases investors' estimate of the stock's beta, but does not affect the stock's future cash flows. On Wednesday, the stock's price falls (negative contemporaneous return) because a higher beta lowers the present value of all future cash flows. This causes the stock's expected future return to be higher. For volume shocks to indicate risk levels that affect future returns, they must have an immediate effect on prices in the opposite direction. Thus, the differential risk hypothesis predicts that high announcement period volume should be accompanied by low announcement period returns.

The visibility hypothesis predicts the opposite. That is, if announcement period volume is positively associated with changes in stock visibility, the effects of that change may begin immediately causing a positive relation between volume and returns. We, therefore, test for a relation between announcement period trading volume and returns, after controlling for earnings forecast errors and other relevant variables.

\subsection{2.e. Additional visibility tests}

Finally, we consider evidence related solely to the visibility hypothesis of Gervais et al [2001]. First, we examine the effects of prior visibility of the high-volume return premium. If volume shocks cause — or are indicators of — changes in stock visibility, then the less previously visible the stock, the greater the impact of a given volume shock. Imagine that Microsoft experiences an event that causes a volume shock. Since a very high fraction of all investors are 
already well aware of Microsoft's existence, this event should have little impact on Microsoft's upcoming returns. If, on the other hand, a small poorly followed or neglected stock experiences the same volume shock, we might expect a much larger effect on upcoming returns. We therefore test for differences in the magnitude of the high-volume return premium based on firm size, analyst following, and market-to-book ratio. Lastly, we measure visibility as a function of news coverage around the earnings announcements and test whether abnormal announcement period trading volume is related to the change in the number of news stories about a firm.

\section{Variable Definitions and Sample Selection}

\subsection{ESTIMATION OF FORECAST ERRORS}

We estimate earnings surprises using two approaches: the historical time-series model based on Compustat earnings data and the analysts' forecasts model based on I/B/E/S data. We define standardized unexpected earnings (SUE) as deflated errors from a seasonal random walk (SRW) model with drift. ${ }^{5}$ Specifically, for each firm-quarter, we begin by estimating the following model:

$$
E_{j, t}=\delta_{j, t}+E_{j, t-4}+\varepsilon_{j, t}
$$

where $E_{j, t}$ is quarterly diluted Earnings Per Share (EPS) before extraordinary items for firm $j$ in quarter $t ; \delta_{j, t}$ is a drift term to allow for the firm's recent historical earnings growth; and $\varepsilon_{j, t}$ is the error term with standard deviation $S T D_{j, t}$. To compute the earnings surprise for quarter $t$, we use the unrestated earnings data from quarters $t-8$ through $t-1$ available in the Charter Oak database through WRDS and the preliminary earnings for quarter $t$ from the preliminary data of Charter Oak. This ensures that the time-series forecast we use, as well as the preliminary earnings, are based on information that investors actually had when earnings were announced,

\footnotetext{
${ }^{5}$ Foster, Olsen, and Shevlin [1984] state that SRW forecast errors perform as well as more sophisticated time series techniques in predicting post-announcement returns.
} 
rather than the restated quarterly earnings in the typical Compustat database (see Livnat and Mendenhall [2006]).

The time-series measure of earnings surprise, $\mathrm{SUE}_{\mathrm{j}, \mathrm{t}}$, is then defined as:

$$
S U E_{j, t}=\frac{E_{j, t}-\delta_{j, t}-E_{j, t-4}}{S T D_{j, t}}
$$

Our second approach estimates earnings surprises using actual earnings and expected earnings from $\mathrm{I} / \mathrm{B} / \mathrm{E} / \mathrm{S}$. We define the standardized unexpected earnings using analysts' forecasts $\left(\mathrm{SUEAF}_{\mathrm{j}, \mathrm{t}}\right)$ as:

$$
\operatorname{SUEAF} F_{j, t}=\frac{E_{j, t}^{i b e s}-F_{j, t}}{\operatorname{StDev}\left(F_{j, t}\right)}
$$

where $E_{j, t}^{\text {ibes }}$ is the actual EPS reported in $\mathrm{I} / \mathrm{B} / \mathrm{E} / \mathrm{S}$ and $F_{j, t}$ is the mean of the most recent forecasts made by each analyst in the 90-day period prior to the earnings announcement. The surprise is then scaled by the standard deviation of these EPS forecasts.

\subsection{ESTIMATING ABNORMAL ANNOUNCEMENT PERIOD VOLUME}

We estimate abnormal earnings announcement period volume as average daily share trading volume over the three-days around the announcement (days -1 through +1 relative to the Compustat earnings report date) divided by the average daily share volume estimated over days 8 through -63 relative to the earnings announcement, minus one. We take volume figures from CRSP. We designate the abnormal volume for firm $j$ in quarter $t$ as $\operatorname{VOLUME}_{\mathrm{j}, \mathrm{t}}$ :

$$
\operatorname{VOLUME} E_{j, t}=\frac{A v g_{d \in[-1,+1]}\left[\operatorname{VOL}_{j, t, d}\right]}{A v g_{d \in[-63,-8]}\left[V O L_{j, t, d}\right]}-1
$$

The abnormal trading volume measures the percentage of changes in daily trading volume during the event period relative to the non-event period. We exclude observations where the average volume in the non-event period is equal to zero. 


\subsection{ESTIMATING ABNORMAL RETURNS}

For firm $j$ in quarter $t$, we define the earnings announcement period abnormal return $\left(\mathrm{EAR}_{\mathrm{j}, \mathrm{t}}\right)$ as the compound (buy and hold) raw stock return for days -1 through +1 relative to the Compustat earnings report date minus the compound return over the same period on a valueweighted portfolio of companies matched on market capitalization (size) and book-to-market $(\mathrm{B} / \mathrm{M})$ ratios. The value-weighted portfolios are based on partitioning all NYSE and Nasdaq stocks into six (two size and three B/M) subsamples. We take the cut-off points to determine the size and $\mathrm{B} / \mathrm{M}$ matched portfolios and the daily returns for these matched portfolios from Professor Kenneth French's data library. ${ }^{6}$

We define stock $j$ 's post-earnings announcement drift for quarter $t\left(\mathrm{DRIFT}_{\mathrm{j}, \mathrm{t}}\right)$ similarly. We begin by computing stock $j$ 's compound (buy and hold) raw return from two days following the preliminary earnings announcement for quarter $t$ through one day after the preliminary earnings announcement for quarter $t+1$, if available, and 100 calendar days if unavailable. We then subtract the compound return over the same period on the value-weighted portfolio of firms with similar size and book-to-market $(\mathrm{B} / \mathrm{M})$ ratios as described above.

Finally, we group companies with fiscal quarters ending within a particular calendar quarter into quarter cohorts. For example, the first calendar quarter of 1999 includes all firmquarters whose fiscal quarters end from January through March 1999. Within each quarter, we independently assign the companies into deciles based on their SUE, SUEAF, EAR and VOLUME ranks. ${ }^{7}$ For use in regression analysis, we scale the decile ranks between 0 and 1 and then subtract 0.5 to assign a score of 0 to the hypothetical median observation. Thus, the adjusted decile ranks are between -0.5 and 0.5 and are labeled respectively dSUE, dSUEAF, dEAR, and dVOLUME. When analyzing the top (bottom) quintile of any of the variables we aggregate the top (bottom) two deciles for that variable.

\footnotetext{
${ }^{6}$ The library is at http://mba.tuck.dartmouth.edu/pages/faculty/ken.french/data_library.html.

${ }^{7}$ While some papers assign ranks based on the forecast error distribution in quarter $t-1$, Bernard and Thomas (1990) report that the drift is insensitive to this research design choice.
} 


\subsection{ESTIMATING FORECAST REVISION AND CHANGE IN DISPERSION}

For some tests we use the analyst forecast revision and change in analyst forecast dispersion measured from before to after the earnings announcement. To calculate these measures we retain EPS estimates for the fiscal year made within 60 days prior to the current quarter's earnings announcements and those made within 30 days subsequent to that announcement. ${ }^{8}{ }^{9} \mathrm{We}$ require both the pre and the post window to have at least 2 analyst forecasts. We calculate the change in dispersion as the difference between the standard deviation of forecasts in the pre period and the standard deviation of forecasts in the post period, each scaled by the absolute value of the mean of forecasts in the pre and post periods respectively. Thus, the changed in scaled dispersions for firm $j$ in quarter $t$ is $\Delta$ DISP $_{\mathrm{j}, t}$ :

$$
\text { change DISP } P_{j, t}=\frac{\operatorname{St}_{\operatorname{Dev}} \operatorname{Dep}_{[0,+30]}\left(F_{j, t}\right)}{\operatorname{abs}\left[\operatorname{Avg}_{[0,+30]}\left(F_{j, t}\right)\right]}-\frac{\operatorname{St} \operatorname{Dev}_{[-60,-1]}\left(F_{j, t}\right)}{\operatorname{abs}\left[\operatorname{Avg}_{[-60,-1]}\left(F_{j, t}\right)\right]}
$$

The forecast revision is calculated as the difference between the mean of forecasts in the pre period and the mean of forecasts in the post period, divided by the stock price at quarter end, and designated for firm $j$ in quarter $t$ as $\operatorname{REV}_{\mathrm{j}, \mathrm{t}}:$

$$
R E V_{j, t}=\frac{A v g_{[0,+30]}\left(F_{j, t}\right)-A v g_{[-60,-1]}\left(F_{j, t}\right)}{\text { Price }_{j, t}}
$$

In both equations $F_{j, t}$ is an individual analyst's EPS forecast for this fiscal year (or for the following fiscal year if current quarter is the fourth fiscal quarter).

\subsection{OTHER VARIABLES}

For the last section we use market capitalization and market-to-book ratio as measures of visibility. We obtain both the market and book values of equity from Compustat industrial quarterly data files. We also obtain news coverage data from Professor Paul C. Tetlock. The data consists of all relevant news articles for S\&P 500 firms appearing in The Wall Street Journal and

\footnotetext{
${ }^{8}$ We retain the latest (earliest) estimate from a given analyst in the pre (post) period.

${ }^{9}$ Alternatively, we use quarterly estimates and obtain qualitatively same results, although the number of observations is greatly reduced.
} 
Dow Jones News Service from the beginning of our sample through December 2004, as obtained from the Factiva database. ${ }^{10}$

\subsection{SAMPLE SELECTION}

We require firm-quarter observations to have non-missing data for the calculation of SUE, SUEAF, VOLUME, EAR, and DRIFT variables. Our sample begins with all stocks listed on the New York Stock Exchange (NYSE), the American Stock Exchange (AMEX), and on Nasdaq between 1987 and 2006. For a firm-quarter observation to qualify for our initial sample, we require the following Compustat data: earnings per share at the preliminary earnings announcement, earnings per share for the most recent 13 quarters, relevant adjustment factors, the preliminary earnings announcement date, stock price at quarter end and average market capitalization of at least $\$ 1$ million. We require at least one analyst quarterly forecast in the 90 days prior to the earnings announcement date and that actual earnings per share and the preliminary earnings announcement date are available from $I / B / E / S$. We require that average volume obtained from CRSP be non-zero in the non-event period prior to the earnings announcement and be non-missing in the three days surrounding the announcement, and that buy and hold returns may be calculated around the announcement and through the earning announcement date of the subsequent quarter. We also require that the Compustat and $I / B / E / S$ earnings announcement dates agree to within two calendar days to ensure that we have lined up Compustat and $I / B / E / S$ data properly and to ensure we have a close earnings announcement date approximation. The resulting sample consists of 146,706 firm quarter observations from the $3^{\text {rd }}$ quarter of 1987 through the $3^{\text {rd }}$ quarter of 2006. Panel A of Table 1 provides sample descriptive statistics and Panel B shows the Spearman correlations among the variables. For tests requiring analyst annual forecast revisions and changes in dispersion, the sample consists of 69,971 firm quarter observations. For tests requiring news coverage data, the sample consists of 19,491 firm

\footnotetext{
${ }^{10}$ For definition of relevant articles and other data generation details see Tetlock, Saar-Tsechansky, and Macskassy [2007].
} 
quarter observations (requiring that a firm has at least one relevant article either in the 30 days preceding or following the earnings announcement date).

\section{Empirical Results}

\subsection{THE HIGH-VOLUME RETURN PREMIUM AND POST-EARNINGS ANNOUNCEMENT DRIFT}

In Table 2, we split the sample into 25 cells based on SUEAF and VOLUME quintiles. For each SUEAF (VOLUME) quintile, the difference in post-announcement returns between the top and bottom VOLUME (SUEAF) quintiles is statistically significant. Further, the cell with the highest VOLUME and highest SUEAF has the highest return, while the cell with the lowest VOLUME and SUEAF has the lowest returns. The spread in quarterly returns from high- to lowVOLUME quintiles is $2.71 \%(2.07 \%$ - $[-0.64 \%])$ and the spread between high and low SUEAF quintile returns is $4.31 \%(2.58 \%$ - [-1.73\%]), while the spread between the highest-VOLUME / SUEAF cell and the lowest-VOLUME/ SUEAF cell is 7.64\% (4.97\% - [-2.67\%]). Despite observations in the highest- and lowest-VOLUME/SUEAF cells being potentially the most profitable (as longs and shorts, respectively), they are not rare; these are the only two cells with over 7,000 observations each. The results in Table 2 indicate that the anomalies are complementary — both PEAD and the high-volume return premium persist when defining PEAD using analyst forecast errors. ${ }^{11}$

Next, we use a regression test to explain returns using abnormal volume and all three different measures of earnings surprise found to be relevant in prior literature. Traditionally, PEAD studies used time series forecasts as a surrogate for market expectations. As discussed above, prior literature suggests that analyst forecast errors (SUEAF) and announcement period returns (EAR) also predict post-announcement returns. EAR is the sole variable that Garfinkel and Sokobin [2006] use to control for earnings surprise when testing for the high-volume return premium.

\footnotetext{
${ }^{11}$ Carrying out this tabulation using SUE rather than SUEAF we reach the same conclusions, although magnitudes are somewhat diminished.
} 
Panel A of Table 3 presents the results of regressing quarterly post-earnings announcement returns on coded-decile scores of four variables: the SRW forecast error (dSUE); the analyst forecast error (dSUEAF); the announcement period abnormal return (dEAR); and the abnormal volume around the earnings announcement (dVOLUME). Each of the first three columns tests for the existence of the high-volume return premium when controlling for one measure of earnings surprise. In each case, both abnormal volume and earnings surprise retain significant explanatory power for post-announcement returns. The fourth column of Table 3 reports that all three different measures of earnings surprise, as well as abnormal volume, have incremental ability to explain quarterly post-earnings announcement returns. Thus, abnormal announcement volume, abnormal announcement return, SRW forecast errors, and analyst forecast errors are all complementary in explaining subsequent returns. Since we code the decile scores from -0.5 to 0.5 (a range of 1.0) we may interpret the coefficients as the estimated difference in post-announcement abnormal returns between top- and bottom deciles for that variable. For example, the 0.023 coefficient on VOLUME in the far-right column indicates that the estimated difference in average abnormal returns between stocks in the top VOLUME decile and the bottom VOLUME decile is $2.3 \%$ per quarter, after controlling for the three measures of earnings surprise.

We observe a hierarchy in the ability of the three earnings surprise measures to explain subsequent returns: SUEAF exhibits the highest explanatory power while SUE and EAR are approximately equal. These results are consistent with those of Chan [1996] and Livnat and Mendenhall [2006]. In the regressions employing one measure of earnings surprise (columns 13 ), the explanatory power of volume is lower than that of each of the earnings surprise variables. When all three earnings surprise measures are used together (column 4), however, the explanatory power of volume is similar to, but slightly higher than, that of SUE/EAR.

Panel B of Table 3 presents results based on the regressions of Panel A run separately on the observations of each of the 77 calendar quarters of our sample period. The reported 
coefficients are the equal-weighted averages of the quarterly coefficients and the t-statistics are based on the standard deviations of those coefficients (as in Fama and MacBeth [1973]). Note that the results of the two panels are very similar and inferences are identical. Having verified that the high-volume return premium does indeed exist after controlling for earnings surprise, we now focus on potential causes for this anomaly.

\subsection{TESTS FOR CAUSES OF THE HIGH-VOLUME RETURN PREMIUM}

In this section we perform several tests to discriminate between two possible explanations for the high-volume return premium: visibility versus risk.

\subsubsection{The riskiness of simulated trading strategies.}

We begin by assessing the risk-return statistics of a strategy of buying stocks that exhibit particularly high-announcement period trading volume, while shorting those with particularly low volume. If the high-volume return premium is attributable to risk, then a strategy designed to profit from it should be risky. The top chart of Figure 1 plots the difference in drift returns between top- and bottom-abnormal volume quintiles each calendar quarter. Given this time series, attempts to exploit the high-volume return premium seem to be highly profitable (before considering transactions costs) and not particularly risky. ${ }^{12}$ The average hedge return to this Volume portfolio over the 77 quarters is $2.67 \%$ with a standard deviation of $3.30 \%$. In comparison, the average hedge return to the SUEAF portfolio is $4.42 \%$ with standard deviation of $2.56 \%$ (bottom chart of Figure 1).

The plot of quarterly hedged returns for the high-volume return premium (like that for PEAD), shows that negative returns are few and relatively minor. Given this analysis, we might ask Bernard and Thomas's [1989] question following a similar investigation of PEAD (using SUE), "Where's the risk?" (p.32). While it is always possible that the high-volume return

\footnotetext{
${ }^{12}$ If risk explains the high-volume return premium, then transactions costs are irrelevant. If one argues that an anomaly represents a market inefficiency, trading frictions such as transactions costs may explain why it is not arbitraged away. But market frictions play no role under the argument that the anomaly represents fair compensation for risk.
} 
premium represents compensation for infrequent but catastrophic losses not observed in our 77quarter sample period, those who choose to make this argument must do so without evidence.

\subsubsection{Abnormal volume and signal agreement.}

Battalio and Mendenhall (2005) provide evidence that the earnings expectations of investors who initiate large trades are better approximated by analyst forecasts, while those of investors who initiate small trades are more similar to SRW forecasts. In an attempt to capture this form of opinion divergence, we examine cases where analyst and SRW errors agree and cases where they disagree. If abnormal measures of trading volume are caused primarily by opinion divergence, then contradictory (confirmatory) signals of earnings information content should be associated with higher (lower) volume.

In Table 4 we show the volume for two cases of agreement / disagreement. Panel A considers only those observations for which SUEAF and/or SUE are in the top or bottom quintile. Here we classify these observations into four groups depending on the SUE and SUEAF signals. The upper-left (bottom-right) cell reports the average abnormal volume for those observations for which the signals agree that the news is bad (good). The upper-right and lower-left cells report results when the signals disagree. Note that volume is highest when the signals agree that the earnings news is good and is second highest when the signals agree that the news is bad. Panel B of Table 4 shows similar results for SUEAF and EAR. ${ }^{13}$ If conflicting signals are indicative of belief divergence, then these results suggest that abnormal announcement period volume is not driven primarily by belief divergence. Volume is, however, also related to the information content of the earnings announcement. When the two signals agree, it may be because the information content of the earnings announcement is stronger causing greater trading volume.

Table 5 provides regression results that correspond to the tests in Table 4 . Here we control for the information content of the earnings announcement by including dSUE, dSUEAF, and dEAR as explanatory variables. In Panel A, AGREE is a binary variable that takes on a value

\footnotetext{
${ }^{13}$ When the tests of Table 4 are replicated defining good and bad news as above and below sample medians, results are qualitatively identical to those reported and no inferences are altered.
} 
of 1.0 if SUEAF and SUE are both in the same extreme quintile and a value of zero otherwise. ${ }^{14}$ Note that in each case, when controlling for the information contained in the earnings announcement — using the three different measures of earnings surprise simultaneously—agreeing signals generate greater abnormal volume than disagreeing signals. ${ }^{15}$ To the extent that signal disagreement is indicative of investor opinion divergence, these results are not consistent with a positive relation between abnormal volume and opinion divergence. These results are not, therefore, consistent with the risk-based explanation for the high-volume return premium. Note that results using the Fama-Macbeth specification displayed in Panel B are very similar.

\subsubsection{Analyst earnings forecast dispersion as a measure of opinion divergence.}

In the prior section we examined cases where more and less sophisticated investors might have divergent expectations. To the extent that stock prices are more influenced by sophisticated investors, perhaps the divergence of opinions among them might be more important than the difference in expectations between them and less sophisticated investors. The cross-sectional standard deviation of analysts' forecasts of future earnings would seem to be a natural measure of investor opinion divergence among larger, more sophisticated investors.

Garfinkel and Sokobin [2006] find, however, that measures of analyst forecast dispersion prior to announcements and the change in dispersion around announcements are uncorrelated with their abnormal volume measures. Further, consistent with Ackert and Athanassakos [1997] and Diether et al [2002], they find that analyst forecast dispersion is negatively correlated with future returns.

Using a less restrictive dataset than that used by Garfinkel and Sokobin, we find a significant positive correlation between announcement period abnormal volume and changes in analyst quarterly and annual earnings forecast dispersion surrounding earnings announcements (not tabulated). To further examine whether the changes in dispersion and volume are capturing

\footnotetext{
${ }^{14}$ We obtain similar results when defining AGREE as agreement between SUEAF and EAR.

${ }^{15}$ We replicate the tests of Table 5 after replacing AGREE with GOOD (BAD), which equals to 1 if the two errors are both in the top (bottom) quintile. The coefficients on both GOOD and BAD are statistically significant and of similar magnitude. Thus the findings are not driven by only positive or negative agreement.
} 
similar phenomena, perhaps opinion divergence, we attempt to control for the magnitude of earnings surprise by regressing drift returns on the three earnings surprise measures, volume, changes in analyst forecast dispersion, and forecast revisions. Table 6 presents the results of regressing post-announcement quarterly returns (DRIFT) on decile coded scores of the independent variables used in Table 3 plus two additional decile-coded variables: the change in analyst annual earnings forecast dispersion and the forecast revision. ${ }^{16}$

Panel A of Table 6 provides results for the pooled sample, while Panel B shows results of the Fama-MacBeth tests. Post-announcement returns are increasing in volume and decreasing in the change of dispersion of analysts' earnings forecasts. With more control variables and a sample more than twelve times larger than that of Garfinkel and Sokobin [2006], we find that announcement period abnormal volume and the change in analyst forecast dispersion have opposite effects on post-earnings announcement returns. This casts doubts on volume as a measure of opinion divergence. Further, since the forecast dispersion would seem to be the more direct measure of opinion divergence, the finding that the change in dispersion is negatively related to post-announcement returns suggests that opinion divergence does not represent a priced risk factor. Overall, our findings challenge two links in the chain connecting the high-volume return premium to priced risk.

\subsubsection{The association between abnormal volume and contemporaneous abnormal returns.}

As explained in Section 2 above, for an event to signal price-relevant risk levels that affect future returns, the event must affect current returns in the opposite direction. Thus, riskbased arguments for the high-volume return premium predict a negative association between abnormal volume and contemporaneous returns.

Table 7 partitions the sample into 25 cells based on quintiles of the earnings surprise as measured by SUEAF and abnormal volume (VOLUME). Each cell indicates the earnings

\footnotetext{
${ }^{16}$ We are interested in the relation between change of dispersion and subsequent returns. We include the forecast revision because Easton and Zmijewski (1989) provide results suggesting that the revision contains information about the persistence of the earnings surprise. Note that the forecast dispersion and revision variables are not known ex ante. This test is not, therefore, suggestive of a potentially exploitable trading rule.
} 
announcement abnormal return (EAR). (Table 7 for announcement period returns is analogous to Table 2 for post-announcement returns.) We observe a monotonic positive relationship between SUEAF and EAR (row All) and a generally positive, but not monotonic, relation between VOLUME and EAR (column All). As explained above, under risk-based explanations for the high-volume return premium, we should observe a negative relation between Volume and EAR. This result is, therefore, not consistent with risk-based explanations. ${ }^{17}$

Table 7 shows, however, that the relationship between VOLUME and EAR depends on SUEAF. For example, comparing the first column of Table 5 to the fifth column shows that when the earnings forecast error indicates bad news (good news), the association between VOLUME and EAR is negative (positive). This raises a puzzle with uncertain implications for the highvolume return premium. When accompanied by high volume, bad news events exhibit a stronger immediate price response, but a weaker drift (-6.45\% in Table 7 and $-1.21 \%$ in Table 2 , respectively), whereas good news events exhibit both stronger immediate and subsequent price reactions ( $+6.74 \%$ in Table 7 and $+4.97 \%$ in Table 2 , respectively). Thus, whereas the bad news results are consistent with a risk-based argument: high volume is associated with lower contemporaneous returns and relatively higher future returns, the good news results are not. Taken together, these results indicate that a opinion divergence is not a simple explanation for the high-volume return premium.

In the previous section we examined the effect of another potential measure of opinion divergence - change in dispersion of analysts' forecasts — on post-announcement returns. We found that abnormal volume and change in forecast dispersion had exactly opposite effects on subsequent returns. We now examine the impact of both variables on contemporaneous returns. Because Table 7 shows that the relation between abnormal volume and contemporaneous returns depends on the sign of the analyst forecast error, we now allow the effects of both volume and forecast dispersion to differ by the sign of the coded analyst forecast error.

\footnotetext{
${ }^{17}$ When replacing SUEAF with SUE in the tests of Table 7, no inferences are altered, but magnitudes are somewhat diminished.
} 
For volume, Table 8 confirms the findings in Table 7: when the forecast error is positive, higher volume means higher (more positive) contemporaneous abnormal returns and when the error is negative, higher volume means lower (more negative) returns. Results for the change in analyst forecast error dispersion, however, indicate that, independent of the sign of the analyst forecast error, contemporaneous returns are decreasing in change in dispersion. Once again, taken together, these results are inconsistent with a connection between the high-volume return premium and priced risk.

\subsubsection{Additional visibility tests}

Stocks that are already highly visible because of, for example, their size, should benefit less from an event that attracts the attention of investors. Under visibility-based explanations for the high-volume return premium, therefore, the premium should be decreasing in proxies for prior firm visibility. As surrogates for visibility we use firm size and market-to-book ratio.

Table 9 presents the post-earnings announcement returns tabulated by both volume and proxies for prior visibility. The rows of Panel A break the sample into stocks in the lowestvolume quintile, the middle three volume quintiles, and the highest-volume quintile. The columns break the sample into firms below and above the median in firm size (by quarter). Note that the effect of VOLUME on post-announcement returns is significantly larger for smaller firms. The difference in drift between the highest- and lowest-volume quintiles is $4.08 \%(3.13 \%-[-0.95 \%])$ for smaller firms and is $0.78 \%(0.72 \%-[-0.06])$ for larger firms. Panel B of Table 9 is identical to Panel A except that firms are split by market-to-book ratio instead of size. Results are significant in the same direction as Panel A, but weaker. This may indicate that market-to-book is a noisier proxy for visibility than firm size.

Some may argue that these results are not informative because most or all anomalies are larger for small firms. Using the PEAD literature as an example, there are two primary arguments. Some (e.g., Latane and Jones [1979]) believe that the marginal investors for large firms are more sophisticated than those of small firms. Others (e.g., Bhushan [1994]) claim that, 
since proportional trading costs are smaller for large firms, informed investors drive prices closer to equilibrium values as they immediately respond to earnings announcements. Both of these arguments apply only when the anomaly represents market mispricing. The former suggests the mispricing might be exploitable, while the second implies it is not. But we cannot think of any way in which these results are consistent with risk-based explanations for the high-volume return premium.

Table 10 presents additional analyses using changes in news coverage as a proxy for changes in a stock's visibility. Our measure of the change in news coverage is the log of one plus the number of Wall Street Journal and Dow Jones News Retrieval articles about the firm in the 30 days after (and including) the earnings announcement date minus the log of one plus the number of articles in the 30 days prior to the earnings announcement date. Relative to our other results, the power of these tests is greatly diminished because access to the number of media articles is limited to S\&P 500 firms. This both reduces our sample size and concentrates the sample among larger, better-followed firms for which the magnitude of the high-volume return premium is much less pronounced.

Panel A presents the Spearman correlation of this visibility measure with earnings surprise measures, abnormal volume, PEAD and size of the firm. Notably, the correlation between the change in visibility and volume is very strong, and the correlation between the change in visibility and the subsequent drift is positive and statistically significant. Panel B shows the results of regressing our change in visibility measure on the decile ranks of the earnings surprise measures and abnormal volume. Abnormal announcement-period trading volume does a much better job of explaining a stock's change in visibility than any of the earnings surprise variables. This strongly suggests that volume shocks may cause — or indicate other events that cause - an increase in a stock's visibility, as suggested by Gervais et al [2001]. In addition we examined whether the change press coverage is associated with subsequent drift by regressing the quarterly post-earnings announcement returns on the change in 
news as well as the coded-decile scores of earnings surprise measures and abnormal volume (not tabulated). We find mixed results as the coefficient on the change in news is small in magnitude but statistically significant for the pooled regressions, but not for the quarterly Fama and MacBeth (1973) regressions (the coefficient for the volume variable is still signficant in both). We attribute the lack of association between the change in news coverage and the subsequent returns to the fact that the sample contains the largest and most followed 150 to 400 firms in any given quarter, which are ex ante expected to have the smallest drift.

\section{Conclusion}

Recent research documents a new capital market anomaly: the high-volume return premium. The high-volume return premium is the positive association between short-term (e.g., one- to five-day) trading volume shocks and subsequent returns. Under one explanation for the anomaly, volume shocks cause, or are associated with events that cause, changes in stock visibility. The more positive the volume shock the greater the increase in stock visibility. The change in visibility causes subsequent abnormal returns as some investors who became aware of the stock decide to buy it. The other explanation is that volume shocks are positively associated with investor opinion divergence and opinion divergence is a relevant risk factor. Under this explanation, the high-volume return premium is fair compensation for risk.

In this paper we address two research questions. First, does the high-volume return premium continue to exist following earnings announcements after controlling for earnings forecast errors? We find that announcement period volume as well as three measures of earnings surprise - announcement period abnormal returns, time series forecast errors, and analyst forecast errors - all have incremental explanatory power for subsequent returns, with analyst forecast errors having the greatest influence.

Our second research question is, What is the likely cause for the high-volume return premium? Test results seem to rule out the chain of logic that high volume indicates high opinion divergence, which indicates high risk and high subsequent returns. First, the high-volume return 
premium exists most quarters and strategies of trying to exploit it by buying high-volume stocks and shorting low-volume stocks do not appear particularly risky. Second, when time series and analyst forecast errors contradict each other-a condition presumably indicating a high level of opinion divergence - trading volume is lower than when they agree. Third, the change in analyst forecast dispersion, another proxy for investor opinion divergence, around the time of earnings announcements is negatively correlated with announcement period trading volume and subsequent returns. Fourth, if high announcement period abnormal volume signals high risk, then high volume should be associated with low contemporaneous stock returns. This is not true unconditionally and is not generally true conditioned on earnings forecast error.

Our findings also lend some support for the visibility hypothesis. Specifically, if changes in visibility are responsible for the high-volume return premium, we would expect that it would be greater for firms with lower preannouncement visibility. Consistent with this idea, we show that the premium is greater for smaller, less followed firms. Finally, using the number of firmspecific media articles as a measure of investor attention, we provide evidence suggesting that volume shocks are positively correlated with changes in investor attention.

The high-volume return premium is extremely new and much remains to be learned. We believe we contribute to the literature by showing that the premium is not subsumed by the relation between earnings forecast errors and subsequent returns (post-earnings announcement drift) and that its characteristics are consistent with changes in firm visibility, but not with riskbased explanations. 


\section{REFERENCES}

Ackert, Lucy F. and George Athanassakos. "Prior Uncertainty, Analyst Bias, And Subsequent Abnormal Returns," Journal of Financial Research, 1997, v20(2,Summer), 263-273.

Ball, Ray. "Anomalies In Relationships Between Securities' Yields And Yield-Surrogates," Journal of Financial Economics, 1978, v6(2/3), 103-126.

Ball, Ray. "The Earnings-Price Anomaly," Journal of Accounting and Economics, 1992, v15(2/3), 319-345.

Ball, Ray and Eli Bartov. "How Naïve is the Stock Market's Use of Earnings Information?" Journal of Accounting and Economics, 1996, v21(3), 319-337.

Ball, Ray and Philip Brown. "An Empirical Evaluation Of Accounting Income Numbers," Journal of Accounting Research, 1968, v6(2), 159-178.

Bartov, Eli. "Patterns In Unexpected Earnings As An Explanation For Post-Announcement Drift," The Accounting Review, 1992, v67(3), 610-622.

Bartov, Eli, Suresh Radhakrishnan, and Itzhak Krinsky. "Investor Sophistication And Patterns In Stock Returns After Earnings Announcements," The Accounting Review, 2000, v75(1,Jan), 4363.

Battalio, Robert H. and Richard R. Mendenhall. "Earnings Expectations, Investor Trade Size, And Anomalous Returns Around Earnings Announcements," Journal of Financial Economics, 2005, v77(2,Aug), 289-319.

Bernard, Victor L. and Jacob K. Thomas. "Post-Earnings-Announcement Drift: Delayed Price Response Or Risk Premium?," Journal of Accounting Research, 1989, v27(Supp), 1-48.

Bernard, Victor L. and Jacob K. Thomas. "Evidence That Stock Prices Do Not Fully Reflect The Implications Of Current Earnings For Future Earnings," Journal of Accounting and Economics, 1990, v13(4), 305-340.

Bhushan, Ravi. "An Informational Efficiency Perspective On The Post-Earnings Announcement Drift," Journal of Accounting and Economics, 1994, v18(1), 45-65.

Brand, Michael W., Runeet Kishore, Pedro Santa-Clara, and Mohan Venkatachalam. "Earnings Announcements are Full of Surprises," 2006, Duke University working paper.

Chan, Louis K. C., Narasimhan Jegadeesh, and Josef Lakonishok. "Momentum Strategies," Journal of Finance, 1996, v51(5,Dec), 1681-1713.

Diether, Karl B., Christopher J. Malloy, and Anna Scherbina. "Differences Of Opinion And The Cross Section Of Stock Returns," Journal of Finance, 2002, v57(5,Oct), 2113-2141.

Easton, Peter D. and Mark E. Zmijewski. "Cross-Sectional Variation In The Stock Market Response To Accounting Earnings Announcements," Journal of Accounting and Economics, 1989, v11(2/3), 117-141. 
Fama, Eugene F. and James D. MacBeth. "Risk, Return, And Equilibrium: Empirical Tests," Journal of Political Economy, 1973, v81(3), 607-636.

Foster, George, Chris Olsen, and Terry Shevlin. "Earnings Releases, Anomalies, And The Behavior Of Security Returns," The Accounting Review, 1984, v59(4), 574-603.

Garfinkel, Jon A. and Jonathan Sokobin. "Volume, Opinion Divergence, And Returns: A Study Of Post-Earnings Announcement Drift," Journal of Accounting Research, 2006, v44(1,Mar), 85112.

Gervais, Simon, Ron Kaniel, and Dan H. Mingelgrin. "The High-Volume Return Premium," Journal of Finance, 2001, v56(3,Jun), 877-919.

Hong, Harrison and Jeremy C. Stein. "A Unified Theory Of Underreaction, Momentum Trading, And Overreaction In Asset Markets," Journal of Finance, 1999, v54(6,Dec), 2143-2184.

Jacob, John, Thomas Lys, and Jowell Sabino. "Autocorrelation structure of forecast errors from time-series models: Alternative assessments of the causes of post-earnings announcement drift," Journal of Accounting and Economics, 1999, v28(3), 329-358.

Jegadeesh, Narasimhan and Sheridan Titman. "Returns To Buying Winners And Selling Losers: Implications For Stock Market Efficiency," Journal of Finance, 1993, v48(1), 65-92.

Jones, Charles P. and Robert H. Litzenberger. "Quarterly Earnings Reports And Intermediate Stock Price Trends," Journal of Finance, 1970, v25(1), 143-148.

Joy, O. Maurice, Robert H. Litzenberger, and Richard W. McEnally. "The Adjustment Of Stock Prices To Announcements Of Unanticipated Changes In Quarterly Earnings," Journal of Accounting Research, 1977, v15(2), 207-225.

Latane, Henry A. and Charles P. Jones. "Standardized Unexpected Earnings - A Progress Report," Journal of Finance, 1977, v32(5), 1457-1465.

Latane, Henry A. and Charles P. Jones. "Standardized Unexpected Earnings - 1971-77," Journal of Finance, 1979, v34(3), 717-724.

Lerman, Alina, Joshua Livnat, and Richard R. Mendenhall. "Double Surprises into Higher Future Returns," Financial Analysts Journal, 2007, v63(4), 63-71.

Litzenberger, Robert H., O. Maurice Joy, and Charles P. Jones. "Ordinal Predictions And The Selection Of Common Stocks," Journal of Financial and Quantitative Analysis, 1971, v6(4), 1059-1068.

Livnat, Joshua and Richard R. Mendenhall. "Comparing The Post-Earnings Announcement Drift For Surprises Calculated From Analyst And Time Series Forecasts," Journal of Accounting Research, 2006, v44(1,Mar), 177-205.

Miller, Edward M. "Risk, Uncertainty, And Divergence Of Opinion," Journal of Finance, 1977, v32(4), 1151-1168. 
Rendleman, Richard J., Jr., Charles P. Jones, and Henry A. Latane. "Empirical Anomalies Based On Unexpected Earnings And The Importance Of Risk Adjustment," Journal of Financial Economics, 1982, v10(3), 269-287.

Tetlock, Paul C., Maytal Saar-Tsechansky, and Sofus Macskassy. "More than Words:

Quantifying Language to Measure Firms Fundamentals," Journal of Finance, Forthcoming.

Varian, Hal R. "Divergence Of Opinion In Complete Markets: A Note," Journal of Finance, 1985, v40(1), 309-317. 
Table 1

Descriptive Statistics

Panel A: Summary Statistics

\begin{tabular}{|c|c|c|c|c|c|c|}
\hline & $\mathrm{N}$ & Mean & Std. Dev. & $\begin{array}{l}25 \text { th } \\
\text { Perc. }\end{array}$ & $\begin{array}{l}\text { 50th } \\
\text { Perc. }\end{array}$ & $\begin{array}{l}75 \text { th } \\
\text { Perc. }\end{array}$ \\
\hline \multicolumn{7}{|l|}{ Measure of Surprise } \\
\hline SUEAF (I/B/E/S) & 146,706 & -3.944 & 733.558 & -0.695 & 0.329 & 1.575 \\
\hline SUE (Compustat) & 146,704 & -0.274 & 4.436 & -0.712 & 0.000 & 0.694 \\
\hline \multicolumn{7}{|l|}{ Buy and Hold Returns (\%) } \\
\hline 3-Day Buy \& Hold Return (EAR) & 146,706 & 0.003 & 0.081 & -0.032 & 0.001 & 0.036 \\
\hline Post Earning Announcement Drift & 146,706 & 0.006 & 0.247 & -0.114 & -0.006 & 0.103 \\
\hline \multicolumn{7}{|l|}{ Measure of Volume (\%) } \\
\hline Abnormal Volume & 146,706 & 0.727 & 1.960 & -0.155 & 0.300 & 1.021 \\
\hline \multicolumn{7}{|l|}{ Firm Characteristics } \\
\hline Book Value of Equity ${ }_{t-1}$ & 146,025 & $1,123.39$ & $4,044.33$ & 73.27 & 221.35 & 749.20 \\
\hline Market Value of Equity ${ }_{t}$ & 146,706 & $3,462.50$ & $15,122.66$ & 165.65 & 545.10 & $1,851.77$ \\
\hline Stock Price $_{t}$ & 146,706 & 25.47 & 24.16 & 11.00 & 20.75 & 33.88 \\
\hline
\end{tabular}

Panel B: Spearman Correlation

\begin{tabular}{lrrrrr}
\hline & SUEAF & SUE & EAR & VOLUME & DRIFT \\
\hline SUEAF & 1 & & & & \\
\multirow{2}{*}{ SUE } & & & & & \\
& 0.299 & 1 & & & \\
& $<.0001$ & & & & \\
EAR & 0.270 & 0.148 & 1 & & \\
& $<.0001$ & $<.0001$ & & & \\
& & & & & \\
VOLUME & 0.081 & 0.060 & 0.058 & & \\
& $<.0001$ & $<.0001$ & $<.0001$ & & \\
& & & & & \\
DRIFT & 0.077 & 0.052 & 0.054 & 0.042 & \\
& $<.0001$ & $<.0001$ & $<.0001$ & $<.0001$ & \\
\hline
\end{tabular}

Notes: SUEAF is calculated from the $I / B / E / S$ database as the actual $I / B / E / S$ EPS minus the mean analyst forecast during the 90-day period before the disclosure of earnings, scaled by the standard deviation of the forecasts. SUE is calculated from the Compustat quarterly database as preliminary EPS minus expected EPS from a seasonal random walk with a drift, scaled by the standard deviation of the forecast errors of the seasonal random walk model. We have excluded from the summary statistics two SUE outliers. We include these observations in all analyses since all tests are performed on ranked variables. EAR is the buy and hold return on a stock minus the average return on a matched size-B/M portfolio in the three days around the earnings announcement. DRIFT is the buy and hold return on a stock minus the average return on a matched size-B/M portfolio from two days after the earnings announcement through one day after the subsequent earnings announcement. VOLUME is average shares traded in the three days around the earnings announcement scaled by average shares traded in a preceding non-event period less one. Market (Book) Value of Equity (in \$million) is as of quarter end. Price is as of quarter end. 
Table 2

Post-Earnings Announcement Drift Tabulated by Analyst Earnings Forecast Errors and Abnormal Volume

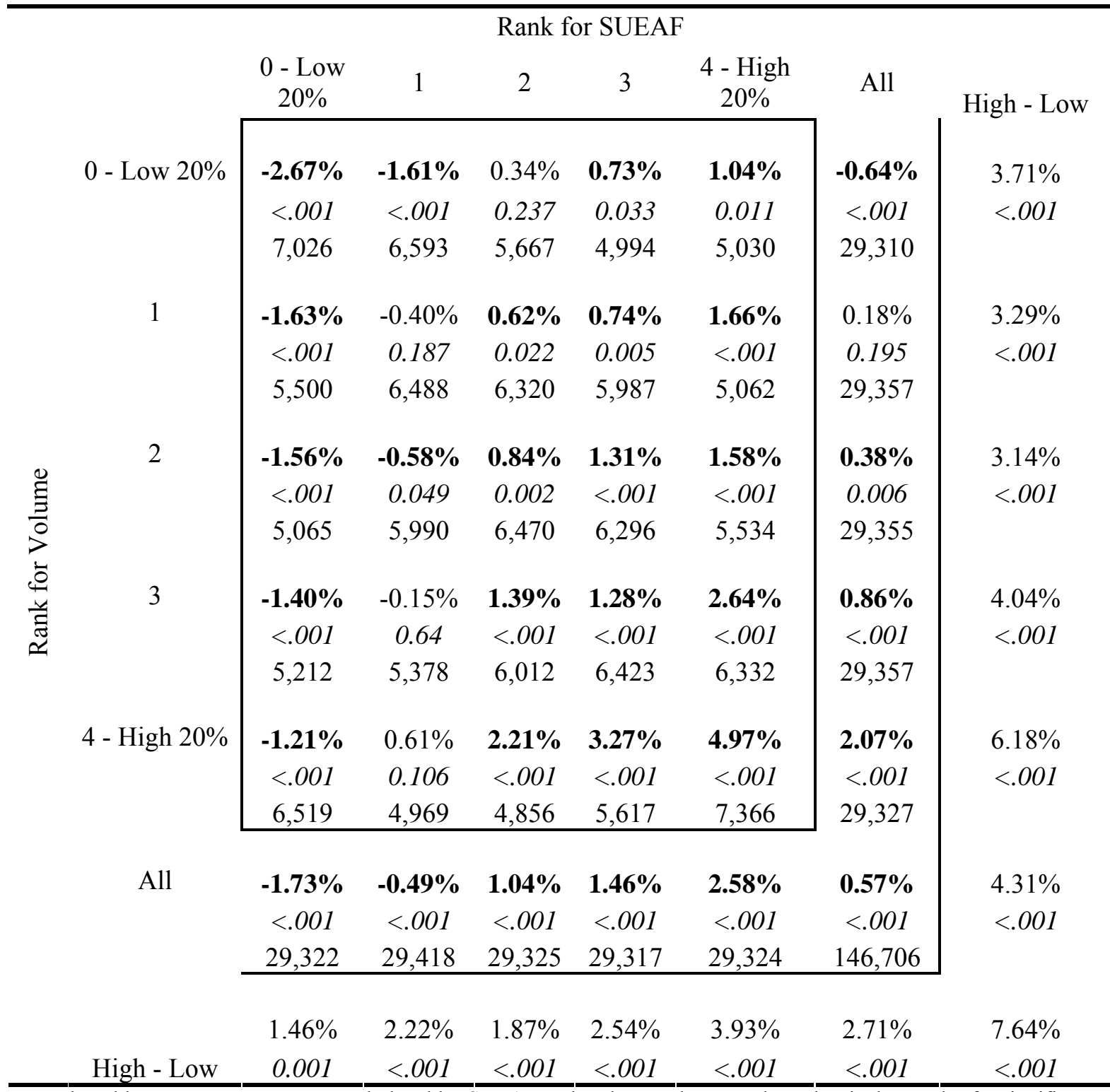

Notes: The table presents mean DRIFT tabulated by SUEAF and Volume. The second number is the result of a significance test that the cell's average return is zero, the bottom number is the number of observations. The p-value for High vs Low here (as well as in other tables) represents the significance probability corresponding to the two-sample t-value tests for the hypothesis that the group means are equal. DRIFT is the buy and hold return on a stock minus the average return on a matched size-B/M portfolio from two days after the earnings announcement through one day after the subsequent earnings announcement. SUEAF is calculated from the $I / B / E / S$ database as the actual $I / B / E / S$ EPS minus the mean analyst forecast during the 90-day period before the disclosure of earnings, scaled by the standard deviation of the forecasts. VOLUME is average shares traded in the three days around the earnings announcement scaled by average shares traded in a preceding non-event period less one. 
Table 3

Regressions of Post-Earnings Announcement Drift on Earnings Surprise and Abnormal Volume

Panel A: Pooled Regressions

\begin{tabular}{|c|c|c|c|c|}
\hline & Reg 1 & Reg 2 & Reg 3 & Reg 4 \\
\hline \multirow[t]{2}{*}{ Intercept } & 0.006 & 0.006 & 0.006 & 0.006 \\
\hline & $(8.85)$ & $(8.85)$ & $(8.85)$ & $(8.85)$ \\
\hline \multirow[t]{2}{*}{ d SUEAF } & 0.046 & & & 0.035 \\
\hline & (22.77) & & & $(15.94)$ \\
\hline \multirow[t]{2}{*}{ d SUE } & & 0.033 & & 0.019 \\
\hline & & $(16.12)$ & & $(9.06)$ \\
\hline \multirow[t]{2}{*}{ d EAR } & & & 0.033 & 0.021 \\
\hline & & & (16.32) & (9.95) \\
\hline \multirow[t]{2}{*}{ d VOLUME } & 0.025 & 0.026 & 0.026 & 0.023 \\
\hline & (12.30) & (12.98) & (12.93) & $(11.51)$ \\
\hline adj $\mathrm{R} 2$ & $0.5 \%$ & $0.3 \%$ & $0.3 \%$ & $0.6 \%$ \\
\hline $\mathrm{N}$ & 146,706 & 146,706 & 146,706 & 146,706 \\
\hline \multicolumn{5}{|c|}{ Panel B: Fama-MacBeth Regressions } \\
\hline & Reg 1 & $\operatorname{Reg} 2$ & Reg 3 & $\operatorname{Reg} 4$ \\
\hline \multirow[t]{2}{*}{ Intercept } & 0.005 & 0.005 & 0.005 & 0.005 \\
\hline & (2.14) & (2.14) & (2.14) & (2.14) \\
\hline \multirow[t]{2}{*}{ d SUEAF } & 0.048 & & & 0.037 \\
\hline & (13.77) & & & (12.06) \\
\hline \multirow[t]{2}{*}{ d SUE } & & 0.033 & & 0.018 \\
\hline & & (7.81) & & (4.58) \\
\hline \multirow[t]{2}{*}{ d EAR } & & & 0.032 & 0.019 \\
\hline & & & (10.04) & (6.16) \\
\hline \multirow[t]{2}{*}{ d VOLUME } & 0.024 & 0.025 & 0.025 & 0.023 \\
\hline & (5.77) & (6.15) & (6.10) & (5.52) \\
\hline $\mathrm{N}$ & 77 & 77 & 77 & 77 \\
\hline
\end{tabular}

Notes: DRIFT is the buy and hold return on a stock minus the average return on a matched size-B/M portfolio from two days after the earnings announcement through one day after the subsequent earnings announcement. SUEAF is calculated from the $I / B / E / S$ database as the actual I/B/E/S EPS minus the mean analyst forecast during the 90 -day period before the disclosure of earnings, scaled by the standard deviation of the forecasts. SUE is calculated from the Compustat quarterly database as preliminary EPS minus expected EPS from a seasonal random walk with a drift, scaled by the standard deviation of the forecast errors of the seasonal random walk model. EAR is the buy and hold return on a stock minus the average return on a matched size-B/M portfolio in the three days around the earnings announcement. VOLUME is average shares traded in the three days around the earnings announcement scaled by average shares traded in a preceding non-event period less one. All independent variables are in decile ranks scaled to fall between -0.5 and 0.5 . 
Table 4

Average Abnormal Volume Where Observe Confirming vs Contradictory Signals

Panel A: SUEAF and SUE

\begin{tabular}{|c|c|c|c|c|c|}
\hline & & & nk for SUI & & \\
\hline & & Bottom 20\% & Top 20\% & All & High vs Low \\
\hline & Bottom 20\% & 0.94 & 0.69 & 0.70 & $<.001$ \\
\hline 㞻 & & 10,300 & 2,859 & 29,310 & \\
\hline co & Top $20 \%$ & 0.78 & 1.15 & 0.85 & $<.001$ \\
\hline 光 & & 3,130 & 9,352 & 29,327 & \\
\hline & All & 0.84 & 0.95 & 0.73 & \\
\hline & & 29,322 & 29,324 & 146,706 & \\
\hline & High vs Low & 0.001 & $<.001$ & & \\
\hline$\underline{\text { Pane }}$ & SUEAF and & ay Buy and Hc & Return (E & & \\
\hline & & & $\mathrm{nk}$ for SUl & & \\
\hline & & Bottom 20\% & Top 20\% & All & High vs Low \\
\hline & Bottom 20\% & 1.48 & 1.05 & 1.24 & $<.001$ \\
\hline 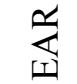 & & 9,992 & 3,270 & 29,310 & \\
\hline कृ & Top 20\% & 1.20 & 1.72 & 1.30 & $<.001$ \\
\hline 䓂 & & 3,334 & 9,342 & 29,327 & \\
\hline & All & 0.84 & 0.95 & 0.73 & \\
\hline & & 29,322 & 29,324 & 146,706 & \\
\hline
\end{tabular}

High vs Low $\quad<.001 \quad<.001$

Notes: SUEAF is calculated from the $I / B / E / S$ database as the actual $I / B / E / S$ EPS minus the mean analyst forecast during the 90 -day period before the disclosure of earnings, scaled by the standard deviation of the forecasts. SUE is calculated from the Compustat quarterly database as preliminary EPS minus expected EPS from a seasonal random walk with a drift, scaled by the standard deviation of the forecast errors of the seasonal random walk model. EAR is the buy and hold return on a stock minus the average return on a matched size- $\mathrm{B} / \mathrm{M}$ portfolio in the three days around the earnings announcement. VOLUME is average shares traded in the three days around the earnings announcement scaled by average shares traded in a preceding non-event period less one. All entries are statistically different from zero at the $.1 \%$ level. 
Table 5

Regressions of Abnormal Volume on Earnings Surprise and Signal Agreement

Panel A: Pooled Regressions

\begin{tabular}{lrrrr}
\hline & Reg 1 & Reg 2 & Reg 3 & Reg 4 \\
\hline Intercept & -0.007 & -0.007 & -0.007 & -0.007 \\
& $(-7.77)$ & $(-7.71)$ & $(-7.75)$ & $(-7.90)$ \\
d SUEAF & 0.072 & & & 0.050 \\
& $(27.83)$ & & & $(17.68)$ \\
d SUE & & 0.060 & & 0.039 \\
& & $(22.91)$ & & $(14.14)$ \\
d EAR & & & 0.061 & 0.042 \\
& & & $(23.33)$ & $(15.37)$ \\
AGREE & 0.052 & 0.052 & 0.051 & 0.053 \\
& $(21.35)$ & $(21.22)$ & $(20.79)$ & $(21.69)$ \\
\hline & & & & \\
adj R2 & $0.8 \%$ & $0.6 \%$ & $0.7 \%$ & $1.1 \%$ \\
$\mathrm{~N}$ & 146,706 & 146,706 & 146,706 & 146,706 \\
\hline
\end{tabular}

Panel B: Fama-MacBeth Regressions

\begin{tabular}{lrrrr}
\hline & Reg 2 & Reg 1 & Reg 3 & Reg 4 \\
\hline Intercept & -0.007 & -0.007 & -0.007 & -0.007 \\
& $(-14.16)$ & $(-13.94)$ & $(-13.58)$ & $(-14.30)$ \\
d SUEAF & 0.069 & & & 0.047 \\
& $(15.92)$ & & & $(11.13)$ \\
d SUE & & 0.058 & & 0.036 \\
& & $(12.25)$ & & $(8.30)$ \\
d EAR & & & 0.063 & 0.044 \\
& & & $(8.10)$ & $(5.62)$ \\
AGREE & 0.052 & 0.052 & 0.051 & 0.053 \\
& $(14.87)$ & $(14.65)$ & $(14.24)$ & $(15.03)$ \\
\hline
\end{tabular}

$\begin{array}{lllll}\mathrm{N} & 77 & 77 & 77 & 77\end{array}$

Notes: VOLUME is average shares traded in the three days around the earnings announcement scaled by average shares traded in a preceding non-event period less one. SUEAF is calculated from the $I / B / E / S$ database as the actual $I / B / E / S$ EPS minus the mean analyst forecast during the 90-day period before the disclosure of earnings, scaled by the standard deviation of the forecasts. SUE is calculated from the Compustat quarterly database as preliminary EPS minus expected EPS from a seasonal random walk with a drift, scaled by the standard deviation of the forecast errors of the seasonal random walk model. EAR is the buy and hold return on a stock minus the average return on a matched size-B/M portfolio in the three days around the earnings announcement. AGREE equals 1 if both SUE and SUEAF are in the same extreme quintile and 0 otherwise. Both the dependent variable (d VOLUME) and earning surprise independent variables are in decile ranks scaled to fall between -0.5 and 0.5 . All the conclusions remain the same with raw volume as the dependent variable (VOLUME). 
Table 6

Regressions of Post-Earnings Announcement Drift on Earnings Surprise, Abnormal Volume and Analyst Forecast Dispersion and Revision

\begin{tabular}{|c|c|c|c|c|}
\hline & \multicolumn{2}{|c|}{$\begin{array}{l}\text { Panel A: } \\
\text { Pooled Regressions }\end{array}$} & \multicolumn{2}{|c|}{$\begin{array}{l}\text { Panel B: } \\
\text { Fama-MacBeth Regressions }\end{array}$} \\
\hline & Reg 1 & $\operatorname{Reg} 2$ & Reg 1 & $\operatorname{Reg} 2$ \\
\hline \multirow[t]{2}{*}{ Intercept } & 0.004 & 0.005 & 0.005 & 0.005 \\
\hline & (5.39) & $(5.52)$ & $(1.68)$ & $(1.73)$ \\
\hline \multirow[t]{2}{*}{ d SUEAF } & 0.021 & 0.001 & 0.024 & 0.004 \\
\hline & (6.95) & $(0.22)$ & $(4.47)$ & $(0.72)$ \\
\hline \multirow[t]{2}{*}{ d SUE } & 0.016 & 0.010 & 0.014 & 0.008 \\
\hline & (5.74) & (3.71) & (3.02) & (1.79) \\
\hline \multirow[t]{2}{*}{ d EAR } & 0.022 & 0.015 & 0.020 & 0.014 \\
\hline & (7.87) & (5.37) & $(5.10)$ & (3.45) \\
\hline \multirow[t]{2}{*}{ d VOLUME } & 0.017 & 0.017 & 0.017 & 0.017 \\
\hline & $(6.41)$ & (6.33) & $(2.83)$ & $(2.74)$ \\
\hline \multirow[t]{2}{*}{ d Change in DISP } & -0.013 & -0.011 & -0.011 & -0.010 \\
\hline & $(-4.88)$ & $(-4.40)$ & $(-2.73)$ & $(-2.44)$ \\
\hline \multirow[t]{2}{*}{ d REV } & & 0.046 & & 0.048 \\
\hline & & $(14.03)$ & & $(9.94)$ \\
\hline adj R2 & $0.5 \%$ & $0.7 \%$ & & \\
\hline $\mathrm{N}$ & 69,971 & 69,971 & 77 & 77 \\
\hline \multicolumn{5}{|c|}{$\begin{array}{l}\text { Notes: DRIFT is the buy and hold return on a stock minus the average return on a matched size-B/M portfolio from two days } \\
\text { after the earnings announcement through one day after the subsequent earnings announcement. SUEAF is calculated from the } \\
I / B / E / S \text { database as the actual } I / B / E / S \text { EPS minus the mean analyst forecast during the } 90 \text {-day period before the disclosure of } \\
\text { earnings, scaled by the standard deviation of the forecasts. SUE is calculated from the Compustat quarterly database as } \\
\text { preliminary EPS minus expected EPS from a seasonal random walk with a drift, scaled by the standard deviation of the } \\
\text { forecast errors of the seasonal random walk model. EAR is the buy and hold return on a stock minus the average return on a } \\
\text { matched size-B/M portfolio in the three days around the earnings announcement. VOLUME is average shares traded in the } \\
\text { three days around the earnings announcement scaled by average shares traded in a preceding non-event period less one. } \\
\text { Change in DISP is the difference between the standard deviation of forecasts in the post ( } 30 \text { days after earnings } \\
\text { announcement) period and the standard deviation of forecasts in the pre ( } 60 \text { days prior to the earnings announcement) period, } \\
\text { each sealed by the absolute value of the mean of forecasts in the post and pre periods respectively. REV is the difference } \\
\text { between the mean of forecasts in the post period and the mean of forecasts in the pre period, divided by the stock price at } \\
\text { quarter end. All independent variables are in decile ranks scaled to fall between }-0.5 \text { and } 0.5 \text {. }\end{array}$} \\
\hline
\end{tabular}


Table 7

Abnormal 3 Day Returns Around the Earnings Announcement (EAR) by Analyst Earnings Forecast Errors and Abnormal Volume

\begin{tabular}{|c|c|c|c|c|c|c|c|}
\hline \multirow[b]{3}{*}{0 - Low $20 \%$} & \multicolumn{6}{|c|}{ Rank for SUEAF } & \multirow[b]{2}{*}{ High - Low } \\
\hline & $\begin{array}{c}0 \text { - Low } \\
20 \%\end{array}$ & 1 & 2 & 3 & $\begin{array}{c}4 \text { - High } \\
20 \%\end{array}$ & All & \\
\hline & $-1.33 \%$ & $-0.57 \%$ & $-0.24 \%$ & $0.25 \%$ & $0.42 \%$ & $-0.38 \%$ & $1.75 \%$ \\
\hline \multirow{5}{*}{1} & $<.001$ & $<.001$ & $<.001$ & $<.001$ & $<.001$ & $<.001$ & $<.001$ \\
\hline & 7,026 & 6,593 & 5,667 & 4,994 & 5,030 & 29,310 & \\
\hline & $-1.50 \%$ & $-0.46 \%$ & $0.29 \%$ & $0.74 \%$ & $1.22 \%$ & $0.04 \%$ & $2.72 \%$ \\
\hline & $<.001$ & $<.001$ & $<.001$ & $<.001$ & $<.001$ & 0.202 & $<.001$ \\
\hline & 5,500 & 6,488 & 6,320 & 5,987 & 5,062 & 29,357 & \\
\hline \multirow{6}{*}{ 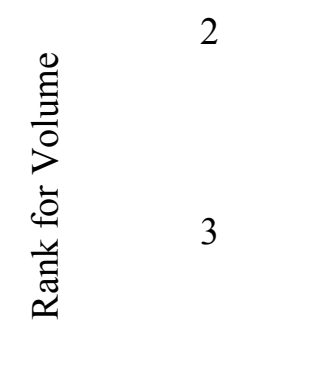 } & $-1.72 \%$ & $-0.40 \%$ & $0.51 \%$ & $1.51 \%$ & $1.91 \%$ & $0.42 \%$ & $3.63 \%$ \\
\hline & $<.001$ & $<.001$ & $<.001$ & $<.001$ & $<.001$ & $<.001$ & $<.001$ \\
\hline & 5,065 & 5,990 & 6,470 & 6,296 & 5,534 & 29,355 & \\
\hline & $-2.45 \%$ & $-0.47 \%$ & $0.98 \%$ & $2.17 \%$ & $3.25 \%$ & $0.86 \%$ & $5.70 \%$ \\
\hline & $<.001$ & $<.001$ & $<.001$ & $<.001$ & $<.001$ & $<.001$ & $<.001$ \\
\hline & 5,212 & 5,378 & 6,012 & 6,423 & 6,332 & 29,357 & \\
\hline \multirow[t]{3}{*}{4 - High $20 \%$} & $-6.45 \%$ & $-3.01 \%$ & $0.25 \%$ & $3.29 \%$ & $6.74 \%$ & $0.42 \%$ & $13.19 \%$ \\
\hline & $<.001$ & $<.001$ & 0.136 & $<.001$ & $<.001$ & $<.001$ & $<.001$ \\
\hline & 6,519 & 4,969 & 4,856 & 5,617 & 7,366 & 29,327 & \\
\hline \multirow[t]{4}{*}{ All } & $-2.77 \%$ & $-0.91 \%$ & $0.37 \%$ & $1.63 \%$ & $3.04 \%$ & $0.27 \%$ & $5.81 \%$ \\
\hline & $<.001$ & $<.001$ & $<.001$ & $<.001$ & $<.001$ & $<.001$ & $<.001$ \\
\hline & 29,322 & 29,418 & 29,325 & 29,317 & 29,324 & 146,706 & \\
\hline & $-5.12 \%$ & $-2.44 \%$ & $0.49 \%$ & $3.04 \%$ & $6.32 \%$ & $0.80 \%$ & $8.07 \%$ \\
\hline High - Low & $<.001$ & $<.001$ & 0.0036 & $<.001$ & $<.001$ & $<.001$ & $<.001$ \\
\hline
\end{tabular}

Notes: The table presents mean EAR tabulated by SUEAF and Volume. The second number is the result of a significance test that the cell's average return is zero, the bottom number is the number of observations. EAR is the buy and hold return on a stock minus the average return on a matched size-B/M portfolio in the three days around the earnings announcement. SUEAF is calculated from the $I / B / E / S$ database as the actual $I / B / E / S$ EPS minus the mean analyst forecast during the 90 -day period before the disclosure of earnings, scaled by the standard deviation of the forecasts. VOLUME is average shares traded in the three days around the earnings announcement scaled by average shares traded in a preceding non-event period less one. 
Table 8

Regressions of Abnormal 3 Day Returns Around the Earnings Announcement (EAR) on Earnings Surprise, Abnormal Volume and Analyst Forecast Dispersion and Revision

Panel A:

Panel B:

Pooled Regressions

Fama-MacBeth Regressions

\begin{tabular}{|c|c|c|c|c|}
\hline & Reg 1 & Reg 2 & Reg 1 & Reg 2 \\
\hline \multirow[t]{2}{*}{ Intercept } & 0.002 & 0.002 & 0.002 & 0.002 \\
\hline & $(7.32)$ & $(8.07)$ & (3.92) & $(4.42)$ \\
\hline \multirow[t]{2}{*}{ d SUEAF } & 0.059 & 0.039 & 0.056 & 0.037 \\
\hline & $(64.12)$ & $(37.81)$ & $(25.48)$ & $(25.56)$ \\
\hline \multirow[t]{2}{*}{ d SUE } & 0.008 & 0.001 & 0.009 & 0.004 \\
\hline & $(8.64)$ & $(1.36)$ & $(9.28)$ & $(3.41)$ \\
\hline \multirow[t]{2}{*}{ d VOLUME (d SUEAF > 0) } & 0.039 & 0.036 & 0.037 & 0.036 \\
\hline & (30.57) & $(29.08)$ & (15.69) & $(15.12)$ \\
\hline \multirow[t]{2}{*}{ d VOLUME (d SUEAF < 0) } & -0.035 & -0.034 & -0.033 & -0.032 \\
\hline & $(-29.07)$ & $(-28.60)$ & $(-11.39)$ & $(-11.39)$ \\
\hline \multirow[t]{2}{*}{ d Change in DISP (d SUEAF > 0) } & -0.007 & -0.006 & -0.007 & -0.006 \\
\hline & $(-5.59)$ & $(-5.07)$ & $(-5.00)$ & $(-4.47)$ \\
\hline \multirow[t]{2}{*}{ d Change in DISP (d SUEAF < 0) } & -0.014 & -0.014 & -0.013 & -0.014 \\
\hline & $(-12.04)$ & $(-12.55)$ & $(-9.56)$ & $(-9.19)$ \\
\hline \multirow[t]{2}{*}{ d REV } & & 0.044 & & 0.041 \\
\hline & & $(43.67)$ & & $(17.17)$ \\
\hline adj R2 & $7.2 \%$ & $9.6 \%$ & & \\
\hline $\mathrm{N}$ & 72,958 & 72,958 & 77 & 77 \\
\hline
\end{tabular}

Notes: EAR is the buy and hold return on a stock minus the average return on a matched size-B/M portfolio in the three days around the earnings announcement. SUEAF is calculated from the $I / B / E / S$ database as the actual $I / B / E / S$ EPS minus the mean analyst forecast during the 90 -day period before the disclosure of earnings, scaled by the standard deviation of the forecasts. SUE is calculated from the Compustat quarterly database as preliminary EPS minus expected EPS from a seasonal random walk with a drift, scaled by the standard deviation of the forecast errors of the seasonal random walk model. VOLUME is average shares traded in the three days around the earnings announcement scaled by average shares traded in a preceding non-event period less one. Change in DISP is the difference between the standard deviation of forecasts in the post period and the standard deviation of forecasts in the pre period, each scaled by the absolute value of the mean of forecasts in the post and pre periods respectively. REV is the difference between the mean of forecasts in the post period and the mean of forecasts in the pre period, divided by the stock price at quarter end. All independent variables are in decile ranks scaled to fall between 0.5 and 0.5 . 


\section{Table 9}

Post-Earnings Announcement Drift for Varying Volume Levels and Dichotomized by Proxies for Visibility.

Panel A: Market Capitalization

Panel B: Market-Book Ratio

\begin{tabular}{ccccc}
\hline $\begin{array}{c}\text { Rank for } \\
\text { Volume }\end{array}$ & Bottom 50\% & Top 50\% & Bottom 50\% & Top 50\% \\
\hline \multirow{2}{*}{ Low 40\% } & $\mathbf{- 0 . 9 5 \%}$ & $\mathbf{- 0 . 0 6 \%}$ & $\mathbf{- 0 . 7 2 \%}$ & $\mathbf{- 0 . 4 7 \%}$ \\
& 19,095 & 10,215 & 17,458 & 11,726 \\
& $<.001$ & 0.752 & $<.001$ & 0.046 \\
Middle 60\% & $\mathbf{0 . 7 9 \%}$ & $\mathbf{0 . 2 3 \%}$ & $\mathbf{0 . 5 2 \%}$ & $\mathbf{0 . 4 3 \%}$ \\
& 37,774 & 50,295 & 42,056 & 45,555 \\
& $<.001$ & 0.006 & $<.001$ & $<.001$ \\
High 40\% & $\mathbf{3 . 1 3 \%}$ & $\mathbf{0 . 7 2 \%}$ & & \\
& 16,462 & 12,865 & $\mathbf{2 . 2 0 \%}$ & $\mathbf{1 . 9 7 \%}$ \\
& $<.001$ & $<.001$ & 13,480 & 15,748 \\
High - Middle & $2.34 \%$ & $0.49 \%$ & $<.001$ & $<.001$ \\
\hline & $<.001$ & 0.009 & $1.67 \%$ & $1.54 \%$ \\
& & & $<.001$ & $<.001$ \\
Middle - Low & $1.74 \%$ & $0.29 \%$ & $1.24 \%$ & $0.90 \%$ \\
& $<.001$ & 0.154 & $<.001$ & 0.000 \\
& & & & \\
High - Low & $4.08 \%$ & $0.78 \%$ & $2.92 \%$ & $2.44 \%$ \\
& $<.001$ & 0.004 & $<.001$ & $<.001$ \\
\hline
\end{tabular}

Notes: DRIFT is the buy and hold return on a stock minus the average return on a matched size-B/M portfolio from two days after the earnings announcement through one day after the subsequent earnings announcement. VOLUME is average shares traded in the three days around the earnings announcement scaled by average shares traded in a preceding non-event period less one. Market (Book) Value of Equity (in \$million) is as of quarter end. The tests for various sub-groups (in the last three rows) are based on two-sample t-statistics. 
Table 10

Change in News Articles Analysis

Panel A: Spearman Correlation

\begin{tabular}{lrrrrrrr}
\hline & SUEAF & SUE & EAR & VOLUME & DRIFT & BOOK & MKT \\
\hline $\log (1+$ News post $)-$ & 0.064 & 0.033 & 0.009 & 0.114 & 0.028 & 0.014 & 0.049 \\
$\log (1+$ News pre $)$ & $<.0001$ & $<.0001$ & 0.2301 & $<.0001$ & 0.0001 & 0.0454 & $<.0001$ \\
& & &
\end{tabular}

Panel B: Regression of Change in News $(\log (1+$ News post $)-\log (1+$ News pre $))$ on Abnormal Volume and Earnings Surprise

\begin{tabular}{|c|c|c|c|c|}
\hline & \multicolumn{2}{|c|}{ Pooled Regressions } & \multicolumn{2}{|c|}{ Fama-MacBeth Regressio } \\
\hline & Reg 1 & $\operatorname{Reg} 2$ & Reg 1 & Reg 2 \\
\hline \multirow[t]{2}{*}{ Intercept } & 0.449 & 0.449 & 0.377 & 0.377 \\
\hline & (79.53) & (79.54) & (10.85) & (10.85) \\
\hline \multirow[t]{2}{*}{ d SUEAF } & & 0.015 & & 0.013 \\
\hline & & $(0.78)$ & & $(0.51)$ \\
\hline \multirow[t]{2}{*}{ d SUE } & & 0.049 & & 0.040 \\
\hline & & $(2.68)$ & & (1.89) \\
\hline \multirow[t]{2}{*}{ d EAR } & & -0.006 & & -0.001 \\
\hline & & $(-0.31)$ & & $(-0.06)$ \\
\hline \multirow[t]{2}{*}{ d VOLUME } & 0.204 & 0.201 & 0.191 & 0.185 \\
\hline & (11.49) & $(11.31)$ & $(10.83)$ & $(10.57)$ \\
\hline
\end{tabular}

$\operatorname{adj} \mathrm{R} 2$

$0.7 \% \quad 0.7 \%$

$\mathrm{N} \quad 19,491 \quad 19,491$

71

71

Notes: News post are news articles on firms in the S\&P 500 Index in the 30 days subsequent to (and including) the earnings announcement and News pre are news articles in the 30 days prior to the earnings announcement. SUEAF is calculated from the $I / B / E / S$ database as the actual $I / B / E / S$ EPS minus the mean analyst forecast during the 90 -day period before the disclosure of earnings, scaled by the standard deviation of the forecasts. SUE is calculated from the Compustat quarterly database as preliminary EPS minus expected EPS from a seasonal random walk with a drift, scaled by the standard deviation of the forecast errors of the seasonal random walk model. EAR is the buy and hold return on a stock minus the average return on a matched size-B/M portfolio in the three days around the earnings announcement. DRIFT is the buy and hold return on a stock minus the average return on a matched size-B/M portfolio from two days after the earnings announcement through one day after the subsequent earnings announcement. VOLUME is average shares traded in the three days around the earnings announcement scaled by average shares traded in a preceding non-event period less one. Market (Book) Value of Equity (in \$million) is as of quarter end of period $\mathrm{t}(\mathrm{t}-1)$. 
Figure 1

\section{Hedge Portfolio Quarterly Drift Returns}

Trading Strategy : VOLUME - long (short) positions in the top (bottom) 20\% of firms sorted according to abnormal volume around the earnings announcement.

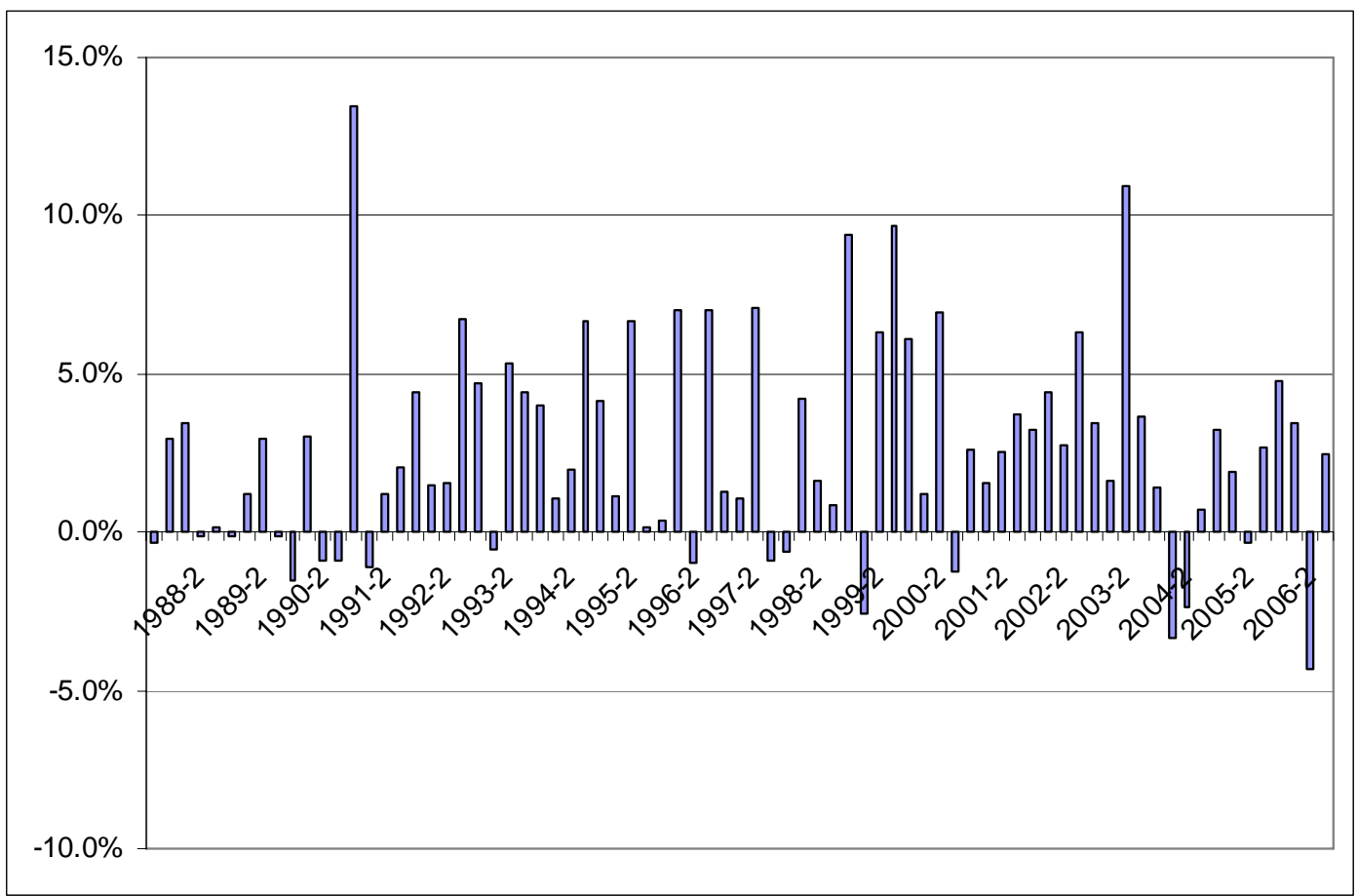

Trading Strategy : SUEAF - long (short) positions in the top (bottom) 20\% of firms sorted according to earnings surprise per analyst forecasts.

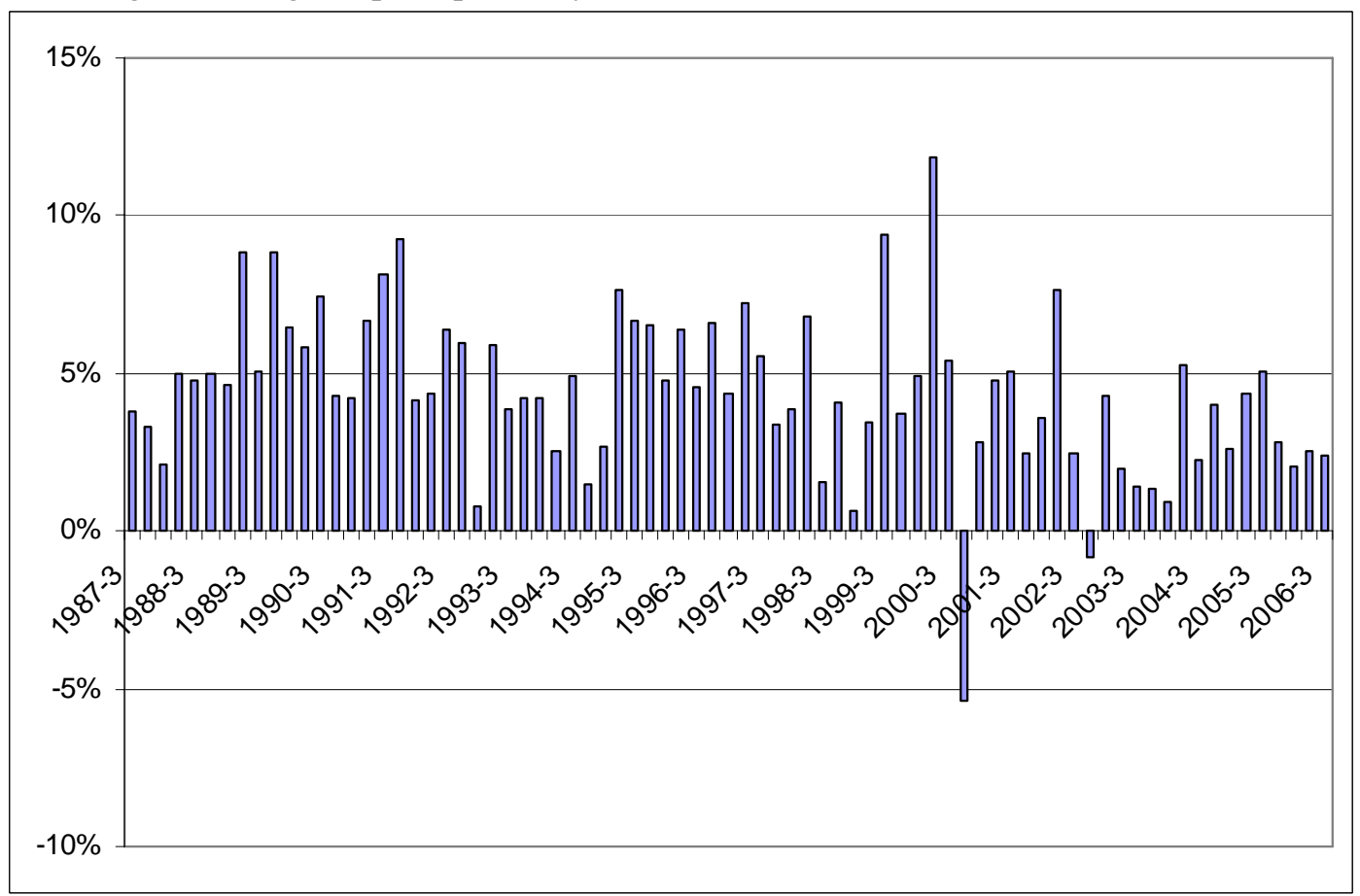

